\title{
Using the Kaleidoscope Career Model to Examine Generational Differences in Work Attitudes
}

\author{
Sherry E. Sullivan \\ Monica L. Forret \\ Shawn M. Carraher \\ Lisa A. Mainiero \\ Fairfield University, Imainiero@fairfield.edu
}

Follow this and additional works at: https://digitalcommons.fairfield.edu/business-facultypubs Copyright 2009 Emerald Publishing

\section{Peer Reviewed}

\section{Repository Citation}

Sullivan, Sherry E.; Forret, Monica L.; Carraher, Shawn M.; and Mainiero, Lisa A., "Using the Kaleidoscope Career Model to Examine Generational Differences in Work Attitudes" (2009). Business Faculty Publications. 62.

https://digitalcommons.fairfield.edu/business-facultypubs/62

\section{Published Citation}

Sullivan, S.E., Forret, M.L., Carraher, S.M., Mainiero, L.A. 2009. "Using the Kaleidoscope Career Model to Examine Generational Differences in Work Attitudes". Career Development International, 14(3), 284-302.

This item has been accepted for inclusion in DigitalCommons@Fairfield by an authorized administrator of DigitalCommons@Fairfield. It is brought to you by DigitalCommons@Fairfield with permission from the rightsholder(s) and is protected by copyright and/or related rights. You are free to use this item in any way that is permitted by the copyright and related rights legislation that applies to your use. For other uses, you need to obtain permission from the rights-holder(s) directly, unless additional rights are indicated by a Creative Commons license in the record and/or on the work itself. For more information, please contact digitalcommons@fairfield.edu. 


\title{
Using the kaleidoscope career model to examine generational differences in work attitudes
}

\author{
The Authors
}

Sherry E. Sullivan, Department of Management, College of Business, Bowling Green State University, Bowling Green, Ohio, USA

Monica L. Forret, Department of Managerial Studies, College of Business, St Ambrose University, Davenport, Iowa, USA

Shawn M. Carraher, School of Business, Cameron University, Lawton, Oklahoma, USA

Lisa A. Mainiero, Department of Management, Charles F. Dolan School of Business, Fairfield University, Fairfield, Connecticut, USA

\section{Acknowledgements}

An earlier version of this paper was presented at the 2009 Southwest Academy of Management Conference and received the McGraw-Hill/Irwin Distinguished Paper Award. The authors also thank Matt Quigley for his comments on earlier drafts of this manuscript.
Abstract
Purpose - The purpose of this paper is to examine, utilising the Kaleidoscope Career Model, whether members of the Baby Boom generation and Generation X differ in their needs for authenticity, balance, and challenge.
Design/methodology/approach - Survey data were obtained from 982 professionals located across the USA. Correlations, $t$-tests, and multiple regressions were performed to test the hypotheses.
Findings - Members of Generation X have higher needs for authenticity and balance than Baby Boomers. There was no difference in needs for challenge between Baby Boomers and members of Generation X.
Research limitations/implications - A limitation in the study, as well as in most of the research on generational differences, is the use of cross-sectional designs that fail to capture the influence of the aging process. A longitudinal, multi-survey design over the lives of individuals would enable scholars to capture within- and between-person differences and to permit a better understanding of whether differences are in fact due to generational effects or to aging. 
Practical implications - Knowledge of the differences and similarities among the various generations in the workforce can help organizational leaders make important decisions about human resource policies and practices.

Originality/value - Many studies in the popular press stress the prevalence and importance of generational differences in the workplace. However, the little academic research that has been conducted has shown mixed results. The study uses the theoretical framework of the Kaleidoscope Career Model to examine generational differences in work attitudes.

\section{Article Type:}

Research paper

Keyword(s):

Careers; Baby boomer generation; Career development.

\section{Journal:}

Career Development International

\section{Volume:}

14

\section{Number:}

3

Year:

2009

pp:

284-302

\section{Copyright (C)}

Emerald Group Publishing Limited

\section{ISSN:}

1362-0436 
Much has been written in the popular press about the clash between Baby Boomers (hereinafter Boomers) and members of Generation X (hereinafter Xers). For instance, Business Week has featured stories such as "The reasons why Gen Xers are unhappy at work," which suggests that Boomer managers do not understand what motivates their Xer employees (Erickson, 2005). Fortune has reported on how Xers feel they cannot get ahead because of the "grey ceiling" created by Boomers who will not retire (Fisher and Bonamici, 2006). Time magazine featured a cover story about Xers that lamented "they just won't grow up" (Grossman, L., 2005) while also illustrating that the generation gap is not just a western phenomenon with its story on "China's me generation" (Simon, 2007). Similar reports of how the generation gap between Boomers and Xers have caused increased workplace conflict have been offered by the Society for Human Resource Management (2004), news organizations such as ABC (Johnson, 2007a, b), and numerous popular press books such as When Generations Collide (Lancaster and Stillman, 2002), Boomers, Xers and Other Strangers (Hicks and Hicks, 1999), and Motivating the "What's In It For Me" Workforce (Marston, 2007).

While the popular press has devoted considerable attention to how the interaction of members from these different generations may have important implications for contemporary workplace dynamics and practices (e.g. Gravett and Throckmorton, 2007; Salkowitz, 2008; Zemke et al., 2000), relatively little academic research has been completed on the topic. The research that has been completed has produced conflicting findings, resulting in a lack of consensus about whether generational differences really do impact work attitudes and behaviors. This lack of consensus is cause for concern given the growing number of practitioner articles and books that encourage managers to lead and motivate members of various generations much differently.

The purpose of this empirical study is to examine potential differences in the career needs of Boomers and Xers, the two generations that dominate today's western workplace. It has been suggested that the root of the conflicts between Boomers and Xers is that these two generations differ in their attitudes toward work-non-work balance, the desire for challenging work, and differences in the meaning of work (e.g. Callanan and Greenhaus, 2008; Hankin, 2004). These differences can be summarized by the description of Boomers as "living to work" and Xers as "working to live." While Boomers are often viewed as workaholics who thrive on increasing work challenge, Xers are seen as placing a higher value on balance to the point of being perceived as slackers. Likewise, Xers are perceived to be more interested in doing work that expresses their personal values than are Boomers, who are perceived to be more interested in material success (e.g. Hankin, 2004). This empirical study addresses whether there are real differences between Boomers and Xers in their desire for authenticity (i.e. need to be genuine), balance, and challenge.

This study also answers Callanan and Greenhaus' (2008) recent "call to action" and their argument that studying generational differences is vital because of the potential implications for organizational human resource planning as well as for individuals enacting their careers. Further, although studies that examine a single generation contribute to the knowledge base by providing detailed insights into that particular group and provide a rich foundation for future research (Broadbridge et al., 2007; Feyerherm and Vick, 2005; McDonald and Hite, 2008; Terjesen et al., 2007), this study takes the next step in the research process. In this study, we used a theory-base coupled with a large, national sample to directly compare two different generations within the 
same study. The findings of this study also suggest implications for organizational leaders who are trying to develop human resource management strategies to attract and retain quality employees from different generations. Managers who have an enhanced understanding of generational differences should be better able to motivate employees of diverse generations resulting in higher productivity and job satisfaction.

We begin by reviewing the social science research on the characteristics of the four major generations of the twentieth century. Next, we review the studies from the organizational sciences which have examined generational differences in the workplace.

Then we provide a brief summary of the Kaleidoscope Career Model (Mainiero and Sullivan, 2005, 2006) and use the model as a framework to propose hypotheses about generational differences and career needs. After a discussion of methods and a presentation of the results, we detail the implications of these findings for future research and practice.

\section{Research on differing generational characteristics}

Over the past 50 years, the examination of generations has been of interest to many different scientific fields including economics, demography, political science, clinical psychology and sociology (Alwin and McCammon, 2007; Biggs, 2007). It is widely held in these fields that certain revolutionary historical events become crystallizing experiences for individuals of shared birth years which bond them together and greatly influence their critical developmental years. These common events shape a generation, influencing members' attitudes and behaviors as this group "travels together through time." Moreover, individuals who share birth years identify with each other as in-group members while others outside of the group recognize them as a distinct generation. Thus, individuals from a respective generation can be differentiated from members of other generations not only by shared birth years but also by the unique social and historical experiences of the members' youths which permanently influenced their characteristics. The four major generations of the twentieth century that have been studied are:

1. the Greatest Generation, born between 1922 and 1945;

2. Boomers, born between 1946 and 1964;

3. Xers, born between 1965 and 1983; and

4. Generation Y (hereinafter Yers), born between 1984 and 2002 (Alwin and McCammon, 2007; Biggs, 2007; Jurkiewicz and Brown, 1998; Kupperschmidt, 2000).

Members of the Greatest Generation share common values based on the key life experiences of the Great Depression, Pearl Harbor, and the Second World War. The Greatest Generation is also called the Silent Generation because they take what life throws at them and remain stoic without complaining about their circumstances. They are self-disciplined, believe in self-sacrifice, and value hard work. They are bound by a strong set of ethical principles that makes them extremely loyal employees. They believe in traditional values and enact traditional gender roles - the husband as breadwinner and the wife as homemaker (Hankin, 2004).

After living through the Great Depression, the Greatest Generation labored to ensure that their Boomer children never wanted for anything and had ample opportunities for a better life. These 
Greatest Generation parents preached the American Dream and instilled Boomers with the belief that hard work and effort would lead to success. Thus, Boomers value extrinsic measures of career success and are willing to work long hours to obtain rewards. Witnessing the Women's Movement, the Civil Rights Movement, and the moon landing, Boomers appreciate the value of working well in teams to achieve goals. Boomers also witnessed great national tragedies including the assassinations of JFK, Bobby Kennedy, and Martin Luther King Jr. Disillusioned by the Vietnam War, Watergate and the resignation of President Nixon, Boomers developed a distrust of authority and place a high value on independent thinking (Callanan and Greenhaus, 2008; Hankin, 2004).

Unlike the Boomers who seem to live to work, it is said that Xers work to live. Xers were greatly influenced by the financial, family and societal insecurities that dominated their childhoods. The downsizing of their Boomer parents in the 1980s and 1990s caused Xers to be distrustful of organizations. Many also experienced the insecurity of being a latchkey child or the child of a single parent as both the number of dual career couples and divorce rates rose. Between the uncertainties of their home lives and the uncertainties of the world, including the destruction of the Berlin Wall and the Challenger disaster, they lack solid traditions but are accustomed to rapid change. They are highly mobile; they are more loyal to work groups and bosses than firms. They dislike hierarchy, believe rewards should be based on merit as opposed to seniority, prefer to work alone, and prefer informal work arrangements. Xers have also been dubbed the "Slacker Generation" because they place a lesser emphasis on work as an important part of their lives, especially in comparison to their Boomer parents (Hankin, 2004; McDonald and Hite, 2008).

While the details of the Greatest Generation, Boomers, and Xers are fairly well developed, the characteristics of the newest members of the workforce, Yers, are less clear. The confusion over how to best describe this generation is illustrated by the number of monikers that have been used to label them, including:

- Generation Why;

- the Millennial Generation;

- the MySpace Generation;

- the Nexters;

- the Internet Generation; and

- the Greater Generation.

The early lives of this generation have been influenced by historical events such as 9/11, the Iraq War, and the O.J. Simpson Trial. Yers cannot remember a time when they were not connected 24/7. They are considered to be the most technologically adept members of the workforce. Their reliance on fast-paced technology; however, often makes them seem impatient (Hankin, 2004; Terjesen et al., 2007).

For the first time in modern history, members from four generations are in the workforce. In 2007, approximately 9 per cent of the workforce were members of the Greatest Generation, 32 per cent were Boomers, 45 per cent were Xers, and 14 per cent were Yers (US Bureau of Labor Statistics, 2008). Although over the last five decades scholars have examined generational conflicts at both the micro level, such as between parents of one generation and children of 
another, and at the macro level, such as generational clashes over social and economic issues including social security and health care policies (Alwin and McCammon, 2007; Biggs, 2007), organizational scholars have just begun to study how generational differences may impact the workplace (e.g. Smola and Sutton, 2002). In the next section we discuss the relatively limited academic research that has been completed on generational differences in the work environment.

\section{Research on generational differences in the workplace}

In one of the first, large scale studies $(n=335)$ to examine generational differences in organizations, Smola and Sutton (2002) compared the work values of Boomers and Xers. Of the twenty significance tests completed, only three resulted in significant generational differences. In line with the idea that Boomers work to live whereas Xers live to work, Boomers were significantly more likely to agree that work should be one of the most important parts of a person's life. Similarly, supporting the idea that Xers favor merit over seniority for performance decisions, Xers were significantly more likely to desire to be promoted quickly. Contrary to the belief that Xers are slackers, Xers were significantly more likely to agree that working hard makes one a better person. Most surprising, however, was the lack of significant generational differences Smola and Sutton (2002) found on most work values, including: being of service to others, feeling more worthwhile for working hard, enjoying work, feeling a sense of pride in one's work, being respected for one's work, getting more money, getting more fringe benefits, being complimented by one's supervisor, and having leisure and free time.

Similar to Smola and Sutton, other organizational researchers have found relatively few of the generational differences suggested by previous research (e.g. Biggs, 2007). Of the nine work outcomes examined by Davis et al. (2006) only three (job involvement, normative organization commitment, and continuance professional commitment) were statistically significant, but just one relationship was in the expected direction. While continuance professional commitment was significantly higher for Boomers than Xers as predicted, contrary to expectations, job involvement and normative organization commitment were significantly higher for Xers. There were no generational differences on factors including work involvement, work group attachment, affective organization commitment, continuance organization commitment, affective professional commitment, and normative professional commitment.

Likewise, Gentry et al. (2009) reported no significant generational differences in Boomers' and Xers' attitudes about learning and development. Despite suggestions that Xers are more protean (Hall, 1976, 1996, 2004) in their beliefs about learning and taking responsibility for their own career development, there were no significant differences between Xers and Boomers in beliefs about the importance of on-the-job learning as well as the belief that their firms develop them as employees. Although it would be expected that Xers would be more likely to intend to engage in developmental learning within the next year, only three of the 29 comparisons about plans to engage in developmental initiatives (e.g. learning another language, development of leadership skills) showed significant generational differences. As to preferences for the use of different developmental techniques (e.g. classroom instruction, web-based training, on-the-job training) for learning soft and hard skills, only six of the 30 comparisons made were significantly different. Overall, their findings suggest few generational differences in attitudes toward learning. 
Sirias et al. (2007) reported mixed results in their study of generational differences and individualism/collectivism. They found that Xers had significantly higher scores on self-reliance, competitiveness and solitary work preferences than Boomers. There were no significant differences between Xers and Boomers on their willingness to sacrifice personal pursuits for the good of the team or in the supremacy of group goals over self-interests (see also Karp et al., 2002).

Using the framework of person-environment fit, Westerman and Yamamura (2007) also reported mixed results. They reported that when Xers and Yers perceived a good fit between their goals and organizational goals, they were significantly more likely to intend to remain with the firm and were more satisfied. However, goal fit had no effect on the satisfaction and intention to remain of Boomers. Relationship fit (e.g. social interaction and work friendships) had a significant effect on the satisfaction of Boomers but had no effect on Boomers' intent to remain. Relationship fit had no influence on intent to remain or satisfaction of Xers or Yers. Because Westerman and Yamamura combined Xers and Yers into one group, differences between these two generations were not considered.

In contrast with much of the previous survey research, Beutell and Wittig-Berman (2008) using archival data from $1997(n=3,552)$ and $2002(n=3,504)$, found significant differences among Matures (i.e. Greatest Generation), Boomers, and Xers in attitudes toward work interfering with family and family interfering with work. There were significant generational differences in work-family synergy for the 1997 sample but not for the 2002 sample. For each generation, job pressures and mental health were the strongest predictors of both types of work-family conflict. Overall, Matures were significantly more satisfied than Boomers and Xers, with Xers being especially concerned about issues of balance.

Unlike most of the studies on generational differences in organizations which used surveys and tended to report mixed results or relatively few differences (see Beutell and Wittig-Berman, $\underline{2008}$, for an exception), Gursoy et al. (2008) used focus groups ( $n=36$ Boomers and 38 Xers) and found consistent generational differences in worldviews. Supporting previous research on generational characteristics, Gursoy et al. (2008) reported that Boomers:

- live to work;

- respect authority and hierarchy; and

- enjoy being in charge.

In contrast, Xers:

- work to live;

- desire instant gratification; and

- are self-reliant.

Like Gursoy et al. (2008), Jovic et al. (2006) used a qualitative approach (i.e. interviews with 34 Boomers and 18 Xers) but also collected quantitative data (i.e. surveys of 87 Boomers and 65 Xers) to examine the work attitudes and behaviors of physicians. Analysis of the interviews suggested that Boomers generally perceived Xers to be less committed to their careers. Boomers 
thought Xers worked fewer hours, worked less hard, and placed a greater emphasis on workfamily balance. Interestingly, while the qualitative data suggested clear generational differences, analysis of the survey data found few significant differences. The quantitative analysis found no significant generational differences in working hours and positive attitudes toward patient care. Likewise, both generations reported similar amounts of balance, that work demands interfered with their family life, and that they lacked time to do the things they wished. The one significant difference between the two generations was that Boomers were more likely to report that their family responsibilities interfered with their work. This study is especially interesting in that most of the Boomers' perceptions of their Gen X colleagues did not match the self-reported attitudes and behaviors of the Gen Xers. These findings suggest that generational clashes may be due, at least in part, to perceptions of differences rather than actual differences between the generations.

Overall, relatively little research has been completed on how generational differences may impact work attitudes and behaviors. Examining the eight major studies that have been published highlights the lack of consensus among organizational scholars about generational differences in the work environment. Because of this lack of agreement, scholars are unable to provide clear recommendations to organizational leaders on how to best manage the increasingly diverse workforce. To advance the research on generational differences, we utilize the Kaleidoscope Career Model (Mainiero and Sullivan, 2006) to provide a theoretical framework for our examination of generational differences in workplace attitudes. The next section provides a description of this model and suggests hypotheses regarding generational differences in the needs for authenticity, balance, and challenge.

\section{The Kaleidoscope Career Model}

The Kaleidoscope Career Model (KCM) is a relatively new career theory that was based on the results of five different studies (interviews, focus groups, and three surveys) of over 3,000 US professional workers (Mainiero and Sullivan, 2006; Sullivan et al., 2007). Like a kaleidoscope that produces changing patterns when the tube is rotated and its glass chips fall into new arrangements, the KCM describes how individuals change the patterns of their careers by rotating the varied aspects of their lives in order to arrange their relationships and roles in new ways. Individuals evaluate the choices and options available through the lens of the kaleidoscope to determine the best fit among work demands, constraints, and opportunities as well as relationships and personal values and interests. As one decision is made, it affects the outcome of the kaleidoscope career pattern.

Just as a kaleidoscope uses three mirrors to create infinite patterns, individuals focus on three parameters when making decisions, thus creating the kaleidoscope pattern of their career. These parameters are:

1. Authenticity. Whereby the individual's internal values are aligned with his/her external behaviors and the values of the employing organization.

2. Balance. Whereby the individual strives to reach an equilibrium between work and nonwork (e.g. family, friends, elderly relatives, personal interests) demands.

3. Challenge. Which is an individual's need for stimulating work (e.g. responsibility, autonomy) as well as career advancement. 
These three parameters are simultaneously active over the life span with the strength of a parameter to shape a career decision or transition depending upon what is going on in that individual's life at that particular time. Over the course of the life span, as a person searches for the best fit that matches the character and context of his/her life, the kaleidoscope's parameters shift in response, with one parameter moving to the foreground and intensifying as that parameter takes priority at that time. The other two parameters lessen in intensity and recede to the background, but are still present and active as all aspects are necessary to create the current pattern of an individual's life/career. Although relatively new, research has supported the basic tenets of the KCM (Cabrera, 2007, in press; Godshalk et al., 2007; Smith-Ruig, 2009).

We framed this study using the non-traditional career model of the KCM as the theory base to examine the career values of Boomers and Xers. We suggest there may be generational differences in the career parameters of authenticity, balance, and challenge. Specifically, Xers, who have been characterized as "working to live" (Gursoy et al., 2008) and being more focused on non-work issues (Beutell and Wittig-Berman, 2008), are expected to exhibit a higher desire for balance than the workaholic Boomers. Likewise, Xers are more likely to exhibit a greater desire for authenticity than the Boomers. It has been suggested that Xers want more meaningful work that permits them to express their values (Westerman and Yamamura, 2007) whereas Boomers are more interested in extrinsic rewards (e.g. Callanan and Greenhaus, 2008; Hankin, 2004). In contrast, it is anticipated that Boomers, who have been characterized as "living to work" and who consider work one of the most important aspects of their lives (Smola and Sutton, 2002), will have a greater desire for challenge than Xers, who have also been called the generation of slackers. Using the KCM as our theoretical foundation, we propose the following hypotheses:

H1. Compared to Boomers, Xers will report a greater desire for authenticity.

H2. Compared to Boomers, Xers will report a greater desire for balance.

H3. Compared Xers, Boomers will report a greater desire for challenge.

\section{Method}

\section{Sample}

In order to collect information from a large sample that was composed of individuals from many different organizations and professions, we chose a web-based approach. We posted our survey on the site of one of the largest established research panels in the USA. Recent research has found that web-based samples compare favorably to traditional survey methods used in psychology. For example, Gosling et al. (2004) reported that internet samples were more representative than traditional pencil-and-paper samples with respect to gender, socioeconomic status, geographic location, and age, and were about as representative as traditional samples with regard to race. Other researchers (e.g. Berrens et al., 2003; Li et al., 2004) have found internet samples to be comparable to large-scale telephone samples in terms of representing the general population. 
A total of 982 surveys were returned, for a response rate of 20 per cent. Individuals ranged in age from 25 to 70. There were no members of Generation Y in the sample. Because of the relatively small number of Greatest Generation members who responded $(n=74)$, we chose to focus on differences between the Boomers and Xers for a usable sample size of 908. The analysis sample was comprised of 463 (51 per cent) Boomers and 445 (49 per cent) Xers.

Of the respondents, 52 per cent were women and 48 per cent were men. Respondents reported their ethnic status as Caucasian (87 per cent), African-American (5 per cent), Asian (5 per cent), and other/prefer not to say ( 3 per cent). The majority of the respondents were married (65 per cent) or living with a partner (9 per cent). Slightly over half of the sample (51 per cent) had at least one child living at home. The educational level of the respondents varied: 15 per cent were high school graduates, 65 per cent attended some college or graduated from college, and 18 per cent had completed some graduate work or held a postgraduate degree. Respondents worked in a wide variety of industries ranging from education (11 per cent), healthcare ( 9 per cent), retail (9 per cent), manufacturing ( 8 per cent), information technology ( 7 per cent), banking/finance (6 per cent), architecture/construction (5 per cent), government (4 per cent), transportation (4 per cent), armed forces ( 2 per cent), leisure/tourism ( 2 per cent) and other ( 33 per cent). The respondents were distributed evenly across the geographic regions (Northeast, South, Midwest, and West) of the USA.

\section{Measures}

Generation. Individuals born between 1965 and 1983 were classified as Xers (coded as 1) and those born between 1946 and 1964 were classified as Boomers (coded as 2).

Authenticity, balance, and challenge. The three parameters of the KCM were measured using a 15-item instrument developed for this study (see Appendix for scale items). Using a five-point scale ranging from 1 "This does not describe me at all" to 5 "This describes me very well", individuals responded to five items per parameter. Coefficient alphas for the authenticity, balance, and challenge scales were $0.76,0.81$, and 0.84 respectively.

\section{Control variables}

In order to determine if differences found were based on generational membership or other individual difference variables, we controlled for factors (e.g. gender, education) that may influence the three career parameters. For instance, previous research (e.g. Mainiero and Sullivan, 2006) reported gender differences and differences due to non-work responsibilities in individuals' preferences for authenticity, balance and challenge:

- Gender. Men were coded as 1 and women were coded as 2.

- Children. Individuals who did not have children living at home were coded with a 1, and those who had children living at home were coded with a 2 .

- Marital status. Individuals who were single, separated, divorced, or widowed were coded as 1, and individuals who were married or living with a partner were coded as 2 .

- Education. Respondents indicated their educational level on a scale ranging from 1 (grade school or less) to 4 (some college) to 8 (postgraduate degree). 
- Income. Respondents indicated their annual household income before taxes on a scale ranging from 1 (less than $\$ 25,000)$ to 8 ( $\$ 150,000$ or more).

\section{Results}

Table I contains the correlations, means, and standard deviations of the study variables. Generational membership was significantly correlated with both authenticity $(r=-0.09)$ and balance ( $r=-0.14$ ) in the hypothesized direction providing initial support for $H 1$ and $H 2$ that Xers would report higher needs for authenticity and balance than Boomers. However, generational membership was not related to challenge in the correlation matrix. $T$-tests were also conducted to examine potential differences between Xers and Boomers. The $t$-tests for authenticity and balance were both significant at the $p<0.01$ level. For authenticity, $M=3.42$ for Xers and 3.25 for Boomers; and for balance, $M=3.44$ for Xers and 3.18 for Boomers. The means for challenge between Xers $(M=3.36)$ and Boomers $(M=3.25)$ were not significantly different.

To perform a more stringent test of our hypotheses, hierarchical multiple regression was performed with the control variables entered as the first block, and generational membership entered as the second block. The results are shown in Table II. In support of H1, Xers reported a greater desire for authenticity than Boomers $(\beta=-0.07, p<0.05)$. $H 2$ was also supported, in that Xers reported a higher need for balance than Boomers $(\beta=-0.09, p<0.01)$. However, contrary to $H 3$, Boomers did not report a greater desire for challenge than Xers.

An examination of the control variables provided additional clarification as to factors associated with desires for authenticity, balance, and challenge. Women and those with higher education reported greater needs for authenticity. Higher needs for balance were reported by those who had children living at home, as well as by those who were married or living with a partner. Finally, those with higher levels of education and income reported greater desires for challenge.

\section{Discussion}

Despite the increased generational diversity in the workplace and increasing questions from organizational leaders about how to strategically manage these valuable resources, there is little consensus among organizational scholars as to whether there are significant differences between Boomers and Xers. Moreover, while scholars in other fields have studied generational differences for decades, relatively speaking, organizational scholars have just begun to examine generational differences in workplace attitudes and behaviors. This study was completed in an effort to shed additional light on this issue by examining whether there are generational differences in the important career needs of authenticity, balance, and challenge.

Using the $\mathrm{KCM}$ as a theory base, this study examined potential generational differences in three work attitudes. As predicted by $H 1$, Xers did have a significantly higher desire for authenticity than Boomers. Although this finding is in contrast to the research of Smola and Sutton (2002) which found no generational differences on a number of other work values (e.g. being of service to others), it does support some research which suggests that Xers are more focused on obtaining a job that they enjoy and allows them to express their personal values (see Callanan and Greenhaus, 2008; McDonald and Hite, 2008). It is also consistent with Westerman and 
Yamamura's (2007) findings that when Xers (and Yers) reported a good fit between their goals and organizational goals, they were significantly more likely to intend to remain with the firm and were more satisfied.

As predicted, Xers did have a significantly higher desire for balance than Boomers. Xers, perhaps because they were the latchkey children of dual career or divorced parents, may wish to obtain a better balance between their work and non-work lives for themselves and for the sake of others (e.g. children, elderly relatives in their care, friends). As suggested by prior research (Beutell and Wittig-Berman, 2008; Gursoy et al., 2008; Smola and Sutton, 2002) it seems while Boomers live to work, Xers work to live. However, in contrast to the findings for authenticity and balance, no significant generational differences were found regarding the desire for challenge. It seems that regardless of generation, individuals want challenging work. While the literature on generational characteristics and research on the protean career suggests that Xers are motivated more by factors like challenging work whereas Boomers are motivated more by money and status, our findings did not support such a difference. Perhaps other factors (e.g. personality, growth need strength) have more influence on needs for challenge than generational membership and should be the subject of further research.

\section{Limitations of the study and directions for future research}

Although this study sheds additional light on generational differences in career needs, it is not without its limitations. First, while a number of disciplines have studied generational characteristics for over 50 years (see Alwin and McCammon, 2007; Biggs, 2007), there has been no agreement among scholars about which birth years should be used to classify individuals into generations. As noted by Smola and Sutton (2002), published research has varied greatly in what birth years have been used (e.g. Boomers beginning anywhere from 1940 to 1946 and ending anywhere between 1960 to 1964). Additionally, questions have been raised if individuals born on the cusp of two generations can be accurately described the same way as individuals whose birthdates clearly fall within assigned ranges (Alwin and McCammon, 2007). This lack of agreement on the classification of generations makes comparisons of findings across different studies problematic, hampers the advancement of this line of research, and may help explain the lack of consensus in research findings. Scholars should consider alternative methods of determining generational membership so there is consistency in classifications across studies. For example, in addition to the use of age, scholars could ask individuals to identify the key historical events from their youth that had a lasting impact on their lives. Such a method may be especially useful in classifying individuals on the cusp between generations.

Second, like most of the research in the organizational sciences, this study is limited by the use of a single survey measurement and a cross-sectional design. Even though the presence of verifiable demographic variables makes the use of a single self-report survey less of a concern (Crampton and Wagner, 1994; Podsakoff and Organ, 1986), we still join other scholars in calling for the increased use of multi-method, longitudinal research designs to study career outcomes (e.g. Sullivan, 1999). The use of longitudinal designs is especially critical when studying generation differences because age rather than generation may be a major factor influencing these results. If we had employed a research design whereby data were collected at multiple times over the life span of individuals, we would have been better able to account for within 
person changes that were due to the aging process in addition to between person differences due to generational membership. The future use of such designs would enable scholars to determine within person changes over time, determine whether other factors such as career stage and the maturation process have more influence on workplace attitudes and behaviors than generational classification, and provide a more complete understanding of this complex phenomenon so that a consensus among scholars about the potential impact of generational differences can be reached.

Third, although the overall regression models for authenticity and balance were statistically significant, it should be noted that the unique change in $R^{2}$ accounted for by generational membership was small. While our use of a large national sample is a strength of the study, it also gives us the power to detect even relatively small differences. In practice, it may be that the importance of generational membership is overshadowed by other potential individual differences (e.g. personality traits). Future research is needed to determine whether generational differences have practical as well as statistical significance when examining individuals' needs for authenticity and balance.

\section{Implications for practice}

Recently there have been calls for more study of generational differences in organizations (e.g. Callanan and Greenhaus, 2008). Specifically, questions have been asked including:

- How can we best manage (Eisner, 2005), communicate (Reynolds et al., 2008), and train (Proserpio and Gioia, 2007) employees of different generations?

- How can we assist members of older generations to best transfer knowledge to the younger generations of workers (Carraher et al., 2008; Kapp, 2007)?

- How can organizations most effectively use generational differences for strategic advantage (Gorman et al., 2004)?

While organizational researchers have begun to study generational differences in the workplace, much more study is needed in order to reach a consensus about these differences so that research-based recommendations can be offered to managers.

Our findings offer important insights for the management of workforces composed of members from different generations. First, because many practitioners are getting their information from popular press books and seminars on managing "clashing" generations, scholars should caution managers not to readily accept sweeping generalities about generational differences without considering both possible similarities among the generations as well as the impact of individual differences. This is especially important when discussing negative perceptions of specific generations which are not empirically supported. For example, despite the belief that Xers are slackers, we found no significant differences in the desire for challenge between Boomers and Xers. Also, because previous research has reported that implementation of employee initiatives (such as those to enhance balance) and use of supportive leadership have been shown to positively impact organizational outcomes (Luthans and Youssef, 2002; Muse et al., 2008; Ozcelik et al., 2008), we suggest that organizations consider instituting such initiatives especially given the growing number of Xers in the workplace who may desire greater balance than previous generations of workers. Employees should not be penalized with reduced challenge for 
participating in such workplace programs. As this study found, challenging work is important to individuals regardless of their generation.

Second, given our finding that Xers were significantly more likely than Boomers to have a higher need for authenticity, managers should consider how to initiate or enhance organizational programs that allow employees, especially Xers, to find a good fit between their values and the organizations' values. For instance, selection programs could make use of realistic job previews (RJPs) (Buckley et al., 2002; Wanous, 1991) and other pre-selection procedures (Buckley et al., 1998) in order to provide a clear picture of the organization's mission and goals to prospective employees. Using the information gleaned from the RJP, an individual could determine if his/her personal values are in alignment with the values of the organization. Organizations could also consider the increased use of employee benefits, such as time off or sabbaticals, so that Xers could choose to work on community or other projects (e.g. environmental issues, campaigns against cancer) that have special meaning to them.

In conclusion, the workforce is increasingly composed of members of different generations who may view career outcomes much differently. The work environment has already seen the impact of this change in the form of increased worker mobility, with careers transforming from traditional linear patterns to more multidirectional forms (Baruch, 2004). Executives and human resource professionals must develop plans for the best management of this diverse labor force in order to recruit and retain the highest quality workers. These employment strategies are even more important as the gap between the demand for highly skilled workers and supply of these workers grows, especially in industries (e.g. health care) which are already facing labor shortages (Carraher et al., 2005, 2006; Ellwood, 2003; Grossman, R.J., 2005). Better understanding of the differences and similarities among the various generations in today's workforce can help organizational leaders make important decisions about human resource policies and practices.

\begin{tabular}{|c|c|c|c|c|c|c|c|c|c|c|c|c|}
\hline & Mean & $\mathrm{SD}$ & 1 & 2 & 3 & 4 & 5 & 6 & 7 & 8 & 9 & \\
\hline $\begin{array}{l}\text { 1. Generation } \\
\text { 2. Authenticity } \\
\text { 3. Balance } \\
\text { 4. Challenge } \\
\text { 5. Gender } \\
\text { 6. Children } \\
\text { 7. Marital status } \\
\text { 8. Education } \\
\text { 9. Income } \\
\text { Notes: }{ }^{*} p \leq 0.05 \text {, }\end{array}$ & $\begin{array}{l}1.51 \\
3.33 \\
3.31 \\
3.31 \\
1.52 \\
1.51 \\
1.74 \\
5.07 \\
4.07 \\
{ }^{* *} p \leq 0\end{array}$ & $\begin{array}{l}0.50 \\
0.89 \\
0.95 \\
0.92 \\
0.50 \\
0.50 \\
0.44 \\
1.64 \\
1.35 \\
n=9\end{array}$ & $\begin{array}{l}-0.09^{* *} \\
-0.14^{* *} \\
-0.06 \\
-0.00 \\
-0.26^{* *} \\
-0.02 \\
-0.02 \\
0.08^{*}\end{array}$ & $\begin{array}{c}(0.76) \\
0.56^{* *} \\
0.56^{* *} \\
0.14^{* *} \\
0.08^{*} \\
0.03 \\
0.07^{*} \\
-0.02\end{array}$ & $\begin{array}{l}(0.81) \\
0.48^{* *} \\
0.07^{*} \\
0.27^{* *} \\
0.18^{* *} \\
0.01 \\
0.07^{*}\end{array}$ & $\begin{array}{l}(0.84) \\
-0.01 \\
0.07^{*} \\
0.03 \\
0.10^{* *} \\
0.11^{* *}\end{array}$ & $\begin{array}{l}\overline{-}^{-} .07^{*} \\
0.10^{* *} \\
-0.06 \\
-0.02\end{array}$ & $\begin{array}{c}\bar{c}-32^{* *} \\
-0.11^{* *} \\
0.00\end{array}$ & $\begin{array}{r}-0.09^{* *} \\
0.13^{* *}\end{array}$ & $0.30^{* *}$ & - & $\begin{array}{r}\text { Table I. } \\
\text { Correlations, means, and } \\
\text { standard deviations of } \\
\text { study variables }\end{array}$ \\
\hline
\end{tabular}

Table ICorrelations, means, and standard deviations of study variables 
Table II.

Regression analyses

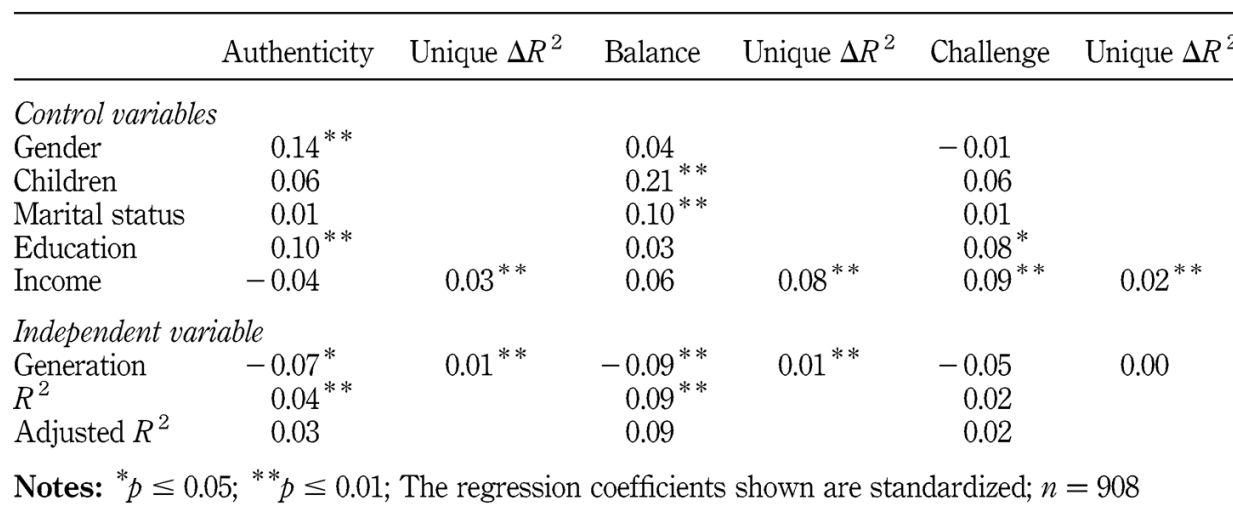

Table IIRegression analyses

\section{Notes}

1. Copyright 2008, Sullivan, Forret, Carraher, and Mainiero. Please contact Sherry Sullivan (ssulliv@bgsu.edu) for permission to use these scales.

\section{References}

Alwin, D.F., McCammon, R.J. (2007), "Rethinking generations", Research in Human Development, Vol. 4 No.3-4, pp.219-37.

[Manual request] [ㅍfotrieve]

Baruch, Y. (2004), "Transforming careers from linear to multidirectional career paths: organizational and individual perspectives", Career Development International, Vol. 9 No.1, pp.58-73.

[Manual request] [ㅍfotrieve]

Berrens, R.P., Bohara, A.K., Jenkins-Smith, H.C., Silva, C.L., Weimer, D.L. (2003), "The advent of internet surveys for political research: a comparison of telephone and internet samples", Political Analysis, Vol. 11 No.1, pp.1-22.

[Manual request] [Infotrieve]

Beutell, N.J., Wittig-Berman, U. (2008), "Work-family conflict and work-family synergy for generation X, baby boomers, and matures: generational differences, predictors, and satisfaction outcomes", Journal of Managerial Psychology, Vol. 23 No.5, pp.507-23.

[Manual request] [Infotrieve]

Biggs, S. (2007), "Thinking about generations: conceptual positions and policy implications", Journal of Social Issues, Vol. 63 No.4, pp.695-711. 


\section{[Manual request] [ํfotrieve]}

Broadbridge, A.M., Maxwell, G.A., Ogden, S.M. (2007), "Experiences, perceptions and expectations of retail employment for generation Y", Career Development International, Vol. 12 No.6, pp.523-44.

[Manual request] [ㅍfotrieve]

Buckley, M., Fedor, D., Veres, J., Wiese, D., Carraher, S. (1998), "Investigating newcomer expectations and job-related outcomes", Journal of Applied Psychology, Vol. 83 No.3, pp.45261.

[Manual request] [ㅍfotrieve]

Buckley, M., Mobbs, T., Mendoza, J., Novicevic, M., Carraher, S., Beu, D. (2002), "Implementing realistic job previews and expectation lowering procedures: a field experiment", Journal of Vocational Behavior, Vol. 61 No.2, pp.263-78.

[Manual request] [Infotrieve]

Cabrera, E.F. (2007), "Opting out and opting in: understanding the complexities of women's career transitions", Career Development International, Vol. 12 No.3, pp.218-37.

[Manual request] [Infotrieve]

Cabrera, E.F. (in press), "Protean organizations: reshaping work and careers to retain female talent", Career Development International, .

[Manual request] [Infotrieve]

Callanan, G.A., Greenhaus, J.H. (2008), "The baby boom generation and career management: a call to action", Advances in Developing Human Resources, Vol. 10 No.1, pp.70-85.

[Manual request] [ㅍfotrieve]

Carraher, S.M., Sullivan, S.E., Carraher, S.C. (2005), "An examination of the stress experienced by entrepreneurial expatriate health care professionals working in Benin, Bolivia, Burkina Faso, Ethiopia, Ghana, Niger, Nigeria, Paraguay, South Africa, and Zambia", International Journal of Entrepreneurship, Vol. 9 No.1, pp.45-65.

[Manual request] [Infotrieve]

Carraher, S.M., Sullivan, S.E., Crocitto, M.M. (2008), "Mentoring across global boundaries: an empirical examination of home- and host-country mentors on expatriate career outcomes", Journal of International Business Studies, Vol. 39 No.8, pp.1310-26. 


\section{[Manual request] [ํfotrieve]}

Carraher, S.M., Parnell, J.A., Carraher, S.C., Carraher, C.E., Sullivan, S.E. (2006), "Customer service, entrepreneurial orientation, and performance: a study in health care organizations in Hong Kong, Italy, New Zealand, the United Kingdom, and the USA", Journal of Applied Management and Entrepreneurship, Vol. 11 No.4, pp.33-48.

[Manual request] [ㅍfotrieve]

Crampton, S.M., Wagner, J.A. III (1994), "Percept-percept inflation in micro-organizational research: an investigation of prevalence and effect", Journal of Applied Psychology, Vol. 79 No.1, pp.67-76.

\section{[Manual request] [Infotrieve]}

Davis, J.B., Pawlowski, S.D., Houston, A. (2006), "Work commitments of baby boomers and gen-xers in the IT profession: generational differences or myth?", Journal of Computer Information Systems, Vol. 46 No.3, pp.43-9.

[Manual request] [ㅍfotrieve]

Eisner, S.P. (2005), "Managing generation Y", SAM Advanced Management Journal, Vol. 70 No.4, pp.4-15.

[Manual request] [ㅍfotrieve]

Ellwood, D. (2003), “Growing faster together or grow slowly apart”, available at: www.aspeninstitute.org (accessed 17 June 2008), .

[Manual request] [Infotrieve]

Erickson, T. (2005), "(2005) The reasons why gen xers are unhappy at work", BusinessWeek Online, (accessed 15 June 2008), No.15 May, .

[Manual request] [Infotrieve]

Feyerherm, A., Vick, Y.H. (2005), "Generation X women in high technology: overcoming gender and generational challenges to succeed in the corporate environment", Career Development International, Vol. 10 No.3, pp.216-27.

\section{[Manual request] [ㅍfotrieve $]$}

Fisher, A., Bonamici, K. (2006), "Have you outgrown your job? a generation of younger workers can't get ahead because the boomers above them won't budge", Fortune, Vol. 154 No.4, pp.4656. 


\section{[Manual request] [ํfotrieve]}

Gentry, W.A., Griggs, T.L., Deal, J.J., Mondore, S.P. (2009), "Generational differences in attitudes, beliefs, and preferences about development and learning at work", in Baugh, S.G., Sullivan, S.E. (Eds), Research in Careers, Information Age Publishing, Charlotte, NC, pp.51-73.

[Manual request] [ㅍfotrieve]

Godshalk, V.M., Noble, A.M., Line, C. (2007), "High achieving women: an exploratory study of the differences between kaleidoscope career types", paper presented at the National Academy of Management meeting, Philadelphia, PA, .

[Manual request] [Infotrieve]

Gorman, P., Nelson, T., Glassman, A. (2004), "The millennial generation: a strategic opportunity", Organizational Analysis, Vol. 12 No.3, pp.255-70.

[Manual request] [ㅍfotrieve]

Gosling, S.D., Vazire, S., Srivastava, S., John, O.P. (2004), "Should we trust web-based studies? A comparative analysis of six preconceptions about internet questionnaires", American Psychologist, Vol. 59 No.2, pp.93-104.

[Manual request] [Infotrieve]

Gravett, L., Throckmorton, R. (2007), Bridging the Generation Gap: How to get Radio Babies, Boomers, Gen Xers, and Gen Yers to Work Together and Achieve More, Career Press, New York, NY, .

[Manual request] [Infotrieve]

Grossman, L. (2005), "Grow up? Not so fast", Time, Vol. 165 No.4, pp.42-54.

[Manual request] [Infotrieve]

Grossman, R.J. (2005), "The truth about the coming labor shortage”, available at: www.shrm.org (accessed 17 June 2008), .

[Manual request] [Infotrieve]

Gursoy, D., Maier, T., Chi, C.G. (2008), "Generational differences: an examination of work values and generation gaps in the hospitality workforce", International Journal of Hospitality Management, Vol. 27 No.3, pp.448-58.

[Manual request] [Infotrieve] 
Hall, D.T. (1976), Careers in Organizations, Goodyear, Pacific Palisades, CA, .

[Manual request] [ํfotrieve]

Hall, D.T. (1996), "Long live the career", in Hall, D.T. (Eds),The Career Is Dead - Long Live the Career, Jossey-Bass, San Francisco, CA, pp.1-12.

[Manual request] [nfotrieve]

Hall, D.T. (2004), "The protean career: a quarter-century journey", Journal of Vocational Behavior, Vol. 65 No.1, pp.1-13.

[Manual request] [ํfotrieve]

Hankin, H. (2004), The New Workforce, AMACOM, New York, NY, .

[Manual request] [Infotrieve]

Hicks, R., Hicks, K. (1999), Boomers, Xers, and Other Strangers, Tyndale House, Wheaton, IL, .

[Manual request] [ํfotrieve]

Johnson, T. (2007a), "Younger boss, older employee: get along on the job", 9 July, available at: ABC News.com (accessed 16 June 2008), .

[Manual request] [ $\underline{\text { Infotrieve] }}$

Johnson, T. (2007b), "Generation gap creates office tension", 4 April, available at: ABC News.com (accessed 16 June 2008), .

[Manual request] [ㅍfotrieve]

Jovic, E., Wallace, J.E., Lemaire, J. (2006), "The generation and gender shifts in medicine: an exploratory survey of internal medicine physicians", BMC Health Services Research, available at: www.biomedicalcentral.com (accessed 16 June 2008), .

[Manual request] [ㅍfotrieve]

Jurkiewicz, C.L., Brown, R.G. (1998), "Gen Xers vs boomers vs matures: generational comparisons of public employee motivation", Review of Public Personnel Administration, Vol. 18 No.4, pp.18-37.

[Manual request] [nfotrieve]

Kapp, K.M. (2007), "Tools and techniques for transferring know-how from boomers to gamers", Global Business and Organizational Excellence, Vol. 26 No.5, pp.22-37. 
[Manual request] [Infotrieve]

Karp, H., Fuller, C., Sirias, D. (2002), Bridging the Boomer Xer Gap, Davies-Black, Palo Alto, $\mathrm{CA}$, .

[Manual request] [ㅍfotrieve]

Kupperschmidt, B.R. (2000), "Multigeneration employees: strategies for effective management", Health Care Manager, Vol. 19 No.1, pp.65-76.

[Manual request] [ํfotrieve]

Lancaster, L.C., Stillman, D. (2002), When Generations Collide: Who They Are, Why They

Clash. How to Solve the Generational Puzzle at Work, HarperBusiness, New York, NY, .

[Manual request] [ํfotrieve]

Li, H., Berrens, R.P., Bohara, A.K., Jenkins-Smith, H.C., Silva, C.L., Weimer, L. (2004),

"Telephone versus internet samples for a national advisory referendum: are the underlying stated preferences the same?", Applied Economics Letters, Vol. 11 No.3, pp.173-6.

[Manual request] [nfotrieve]

Luthans, F., Youssef, C.M. (2002), "Investing in people for competitive advantage", Organizational Dynamics, Vol. 33 No.2, pp.143-60.

[Manual request] [ํfotrieve]

McDonald, K.S., Hite, L.M. (2008), "The next generation of career success: implications for HRD", Advances in Developing Human Resources, Vol. 10 No.1, pp.86-103.

[Manual request] [Infotrieve]

Mainiero, L.A., Sullivan, S.E. (2005), "Kaleidoscope careers: an alternative explanation for the opt-out generation", Academy of Management Executive, Vol. 19 No.1, pp.106-23.

[Manual request] [ํfotrieve]

Mainiero, L.A., Sullivan, S.E. (2006), The Opt-Out Revolt: How People Are Creating Kaleidoscope Careers outside of Companies, Davies-Black, New York, NY, .

[Manual request] [ㅍfotrieve]

Marston, C. (2007), Motivating the "What's in It for Me?" Workforce: Manage across the Generational Divide and Increase Profits, Wiley, New York, NY, . 


\section{[Manual request] [ํotrieve]}

Muse, L., Harris, S.G., Giles, W., Feild, H. (2008), "Work-life benefits and positive organizational behavior: is there a connection?", Journal of Organizational Behavior, Vol. 29 No.2, pp.171-92.

[Manual request] [Infotrieve]

Ozcelik, H., Langton, N., Alrich, H. (2008), "Doing well and doing good: the relationship between leadership practices that facilitate a positive work climate and organization performance", Journal of Managerial Psychology, Vol. 23 No.2, pp.186-203.

[Manual request] [Infotrieve]

Podsakoff, P.M., Organ, D.W. (1986), "Self-reports in organizational research: problems and prospects", Journal of Management, Vol. 12 No.4, pp.531-44.

[Manual request] [Infotrieve]

Proserpio, L., Gioia, D.A. (2007), "Teaching the virtual generation", Academy of Management Learning \& Education, Vol. 6 No.1, pp.69-80.

[Manual request] [Infotrieve]

Reynolds, L., Bush, E.C., Geist, R. (2008), "The Gen Y imperative", Communication World, Vol. 25 No.3, pp.19-22.

[Manual request] [Infotrieve]

Simon, E. (2007), "China's me generation", Time, Vol. 170 No.1, pp.32-7.

[Manual request] [Infotrieve]

Sirias, D., Karp, H.B., Brotherton, T. (2007), "Comparing the levels of individualism/collectivism between baby boomers and Generation X: implications for teamwork", Managerial Research News, Vol. 30 No.10, pp.749-61.

[Manual request] [ㅍfotrieve]

Salkowitz, R. (2008), Generation Blend: Managing across the Technology Age Gap, Wiley, New York, NY, .

[Manual request] [ $\underline{\text { Infotrieve }]}$ 
Smith-Ruig, T. (2009), "Mapping the career journey of accountants in Australia", in Baugh, S.G., Sullivan, S.E. (Eds), Research in Careers, Information Age Publishing, Charlotte, NC, pp.163-96.

[Manual request] [Infotrieve]

Smola, K.W., Sutton, C.D. (2002), "Generational differences: revisiting generational work values for the new millennium", Journal of Organizational Behavior, Vol. 23 No.4, pp.363-82.

[Manual request] [Infotrieve]

Society for Human Resource Management (2004), Generational Differences Survey Report, SHRM, Alexandria, VA, .

[Manual request] [Infotrieve]

Sullivan, S.E. (1999), "The changing nature of careers: a review and research agenda", Journal of Management, Vol. 25 No.3, pp.457-84.

[Manual request] [Infotrieve]

Sullivan, S.E., Forret, M.L., Mainiero, L.A., Terjesen, S. (2007), "What motivates entrepreneurs? An exploratory study of the kaleidoscope career model and entrepreneurship", Journal of Applied Management and Entrepreneurship, Vol. 12 No.4, pp.4-19.

[Manual request] [Infotrieve]

Terjesen, S., Vinnicombe, S., Freeman, C. (2007), "Attracting Generation Y graduates: organizational attributes, likelihood to apply and sex differences", Career Development International, Vol. 12 No.6, pp.504-22.

[Manual request] [Infotrieve]

US Bureau of Labor Statistics (2008), Current Population Survey for 2007, available at: www.bls.gov (accessed 16 June 2008), .

[Manual request] [Infotrieve]

Wanous, J.P. (1991), Organizational Entry, Addison-Wesley, New York, NY, .

[Manual request] [Infotrieve]

Westerman, J.W., Yamamura, J.H. (2007), "Generational preferences for work environment fit: effects and employee outcomes", Career Development International, Vol. 12 No.2, pp.150-61.

[Manual request] [ㅍfotrieve] 
Zemke, R., Raines, C., Filipczak, B. (2000), Generations at Work: Managing the Clash of Veterans, Boomers, Xers, and Nexters in Your Workplace, AMACOM, New York, NY, .

[Manual request] [ํnfotrieve]

\section{Appendix. Authenticity, balance, and challenge scales [1]}

\section{Authenticity}

- I hope to find a greater purpose to my life that suits who I am.

- I hunger for greater spiritual growth in my life.

- I have discovered that crises in life offer perspectives in ways that daily living does not.

- If I could follow my dream right now, I would.

- I want to have an impact and leave my signature on what I accomplish in life.

\section{Balance}

- If necessary, I would give up my work to settle problematic family issues or concerns.

- I constantly arrange my work around my family needs.

- My work is meaningless if I cannot take the time to be with my family.

- Achieving balance between work and family is life's holy grail.

- Nothing matters more to me right now than balancing work with my family responsibilities.

\section{Challenge}

- I continually look for new challenges in everything I do.

- I view setbacks not as "problems" to be overcome but as "challenges" that require solutions.

- Added work responsibilities don't worry me.

- Most people would describe me as being very goal-directed.

- I thrive on work challenges and turn work problems into opportunities for change.

\section{Response scale}

- does not describe me at all.

- describes me somewhat.

- describes me often.

- describes me considerably.

- describes me very well.

\section{About the authors}

Sherry E. Sullivan (PhD, The Ohio State University) has served as Division Chair, Program Chair, Historian, and Newsletter Editor for the Academy of Management's Career Division. She is a Fellow of the Southern Management Association and has published in journals including: 
Journal of Applied Psychology, Journal of Vocational Behavior, Journal of Management, Group and Organization Management, Journal of Managerial Psychology, Academy of Management Executive, and Journal of International Business Studies. She was named the 2008 Southwest Academy of Management Distinguished Educator. She is co-author (with Lisa Mainiero) of The Opt-Out Revolt: Why People Are Leaving Companies to Create Kaleidoscope Careers (Davies Black, 2006) and co-editor (with Yehuda Baruch and Hazlon Schepmyer) of Winning Reviews: A Guide for Evaluating Scholarly Writing $\square$ (Palgrave, 2006). She is also the co-editor (with S. Gayle Baugh) of the Research in Careers series (Information Age Publishing, 2009). She is the corresponding author and can be contacted at: ssulliv@bgsu.edu

Monica L. Forret (PhD, University of Missouri) is a Full Professor at St Ambrose University and is the Director of the Doctor of Business Administration Program. She has published numerous articles in journals including the Journal of Organizational Behavior, Group \& Organization Management, Journal of Vocational Behavior, Career Development International, Leadership \& Organization Development Journal, Journal of Managerial Psychology, Journal of Business and Psychology, Journal of Management Education, Journal of Leadership \& Organizational Studies, Journal of Applied Management and Entrepreneurship, and Organizational Dynamics. Her research interests are primarily in the areas of networking, mentoring, co-worker relationships, job search processes, and career success. She has served on the Board of the Careers Division of the Academy of Management, as the Human Resources/Careers Track Chair of the Midwest Academy of Management, and is an Editorial Board Member for the Journal of Leadership \& Organizational Studies.

Shawn M. Carraher received his PhD from the University of Oklahoma and is the Brewczynski Endowed Chair, Director of the Center for Emerging Technology \& Entrepreneurial Studies, Head of Entrepreneurial Studies, and Director of the Small Business Institute at Cameron University. He currently serves as a Past President of the International Association of SBI Directors, President of the Association for Entrepreneurship, Family Business, \& Franchising, and Division Chair elect of the Technology \& Innovation Management Division of the Academy of Management. With over 110 published articles and data collections in over 110 countries his primary research interests involve an examination of cross-cultural differences in compensation and selection within entrepreneurial organizations with a special focus on tourism and health care. He has also completed three Fulbright trips.

Lisa A. Mainiero, $\mathrm{PhD}$ received her doctorate in organizational behavior from Yale University in 1983. Dr Mainiero's latest book, co-authored with Sherry E. Sullivan, The Opt-Out Revolt: Why People Are Leaving Companies to Create Kaleidoscope Careers (Davies-Black Publishers, 2006) describes contemporary trends in the career landscape for women and for men. $\mathrm{Dr}$ Mainiero has published several articles on executive women's careers, issues of power and politics, and crisis management strategies in journals such as Administrative Science Quarterly, the Academy of Management Review, the Journal of Management, the Academy of Management Executive, and Organizational Dynamics. She currently is a Full Professor of Management at the Charles F. Dolan School of Business at Fairfield University in Fairfield, Connecticut. 